Article

\title{
Study of Temperature Fields and Heavy Metal Content in the Ash and Flue Gas Produced by the Combustion of Briquettes Coming from Paper and Cardboard Waste
}

\author{
Harouna Gado Ibrahim ${ }^{1, *}$, Salifou K. Ouiminga ${ }^{2}$ (1) , Arsène Yonli ${ }^{2}$, Oumar Sanogo ${ }^{3}$, \\ Tizane Daho ${ }^{2}$ and Jean Koulidiati ${ }^{2}$ \\ 1 Département de Physique, Faculté des Sciences et Techniques, Université Dan Dicko Dankoulodo de Maradi, \\ BP, 465 MARADI, Niger \\ 2 LPCE, Département de Physique, Université Joseph Ki-Zerbo de Ougadougou, \\ 03 BP 7021 Ouagadougou 03, Burkina Faso; salif0477@yahoo.com (S.K.O.); yarsene@hotmail.com (A.Y.); \\ tizane_daho@yahoo.fr (T.D.); j.koulidiati@yahoo.fr (J.K.) \\ 3 IRSAT, Institut de Recherche en Sciences Appliquées et Technologies, \\ 03 BP 7047 Ouagadougou, Burkina Faso; sanogo_oumar@hotmail.com \\ * Correspondence: gado_foga@yahoo.fr
}

Received: 16 May 2018; Accepted: 12 July 2018; Published: 13 July 2018

\begin{abstract}
The present study focused on the combustion of four types of briquettes made from paper and cardboard waste produced in Ouagadougou (Burkina Faso). Rotary and tubular kilns were used to study the combustion. The combustion mean temperatures, nitrogen, phosphorus and potassium (NPK) content in the ash and heavy metals content in the ash and the flue gas were analyzed. The combustion steady phase mean temperatures ranged from $950{ }^{\circ} \mathrm{C}$ to $750{ }^{\circ} \mathrm{C}$ were obtained according to briquettes type. The temperature favored the transfer of the heavy metal in the flue gas comparatively to the ash mainly for $\mathrm{Hg}, \mathrm{Cd}$ and $\mathrm{Pb}$. The $\mathrm{Pb}, \mathrm{Hg}$ and $\mathrm{Mn}$ content in flue gas and the ash are higher than their content in the parent wood used for paper production due to the additive during the manufacturing process. The results showed a high content of heavy metal in flue gas produced by combustion of briquette made with office paper and in the ash for the briquette made of corrugated cardboard. Furthermore, the low heavy metal contain in the ash allow their use for soil amendment. However, ash contained a low proportion of NPK (less than $2 \%$ ) which does not allow their usage as fertilizer alone.
\end{abstract}

Keywords: briquettes; ash; nitrogen-phosphorus-potassium; heavy metals

\section{Introduction}

More than two billion people around the world do not have access to modern energy. In Burkina Faso, most of the energy needs are provided by wood (more than $80 \%$ ). The consequence is an increasing scarcity of wood, hence the need to find other sources of energy. This fully justifies the importance of energy recovery from waste, especially paper and cardboard waste. Indeed, the typology of waste from the city of Ouagadougou, the biggest city of Burkina Faso, reveals that paper/cardboard accounts for $10 \%$ of waste, which is more than 20,000 tonnes per year according to the work of Tezanou et al. [1]. This quantity can be valorized energetically or recycled. According to the life cycle analysis conducted by Karna et al. [2], the energy recovery of paper waste contributes less to global warming than recycling. However, the study conducted by Merrild et al. [3] showed that a high-performance recycling process is more beneficial than energy recovery. In the case of Burkina Faso, energy recovery 
is possible because of the absence of a suitable recycling system. Indeed, a little fraction of waste composed of metal, hard plastic and bottles (made of glass or plastic) are recycled by the informal sector. The waste paper and cardboard ends in the landfills. Thus, waste paper and cardboard can be used as fuels in the form of briquettes as proposed in our previous study [4]. The environmental advantages of replacing wood or fuel oil with paper/cardboard briquettes are important (reducing deforestation, reducing the global warming associated with the use of fuel oil, etc.). In addition to recovering the energy released by the combustion of the briquettes, the ashes obtained can also be used to amend the soil. Note that, these ash quantities can achieve $28 \%$ of the mass of the raw paper and cardboard waste [5]. The ash may be used to return nutrients to the soil, thus closing the nutrient cycle and enhancing soil fertility [6,7]. However, the burning of waste paper and cardboard briquettes presents major challenges. Indeed, depending on their nature and their uses, waste paper and cardboard are soiled. In general, the waste paper and cardboard present physical impurities such as staples, sand, plastics, inks... But also chemical and toxic matters as heavy metals $[8,9]$. The heavy metals are also present in the biomass as a micronutrient [10]. These heavy metals may be present in the paper at the end of the manufacturing process. The chemical additives and ink used during the manufacturing process and the usage of the paper and cardboard are probable sources of heavy metals. Indeed, colorants and other additive used to improved paper color and quality content zinc, cadmium, lead and chromium [11]. The ink is composed up to $30 \%$ of pigment which contents many types of heavy metals according to its formulation [12-14]. Thus, during the combustion process the heavy metals can be found in the bottom ash, the fly ash and the flue gas [15]. Heavy metals could cause air, water and soil pollution according to Kovacs et al. [15]. As a result, the combustion and valorization of residual ash are subject to multiple regulations, mainly on the content of heavy metals. The main heavy metals targeted are cadmium (Cd), arsenic (As), lead (Pb) and Zinc ( $\mathrm{Zn}),[16,17]$. This imposes the need for the evaluation of energy performances and environmental impacts with a view to energy recovery of briquettes and ash. For this purpose, the ash compositions of many type of biomass were determined by Jenkins et al. [8]. These authors found a great composition variation of biomass ash; furthermore, the manufacturing process could impact the proportion and the composition of ash coming from biomass like paper and cardboard waste.

Waste paper and cardboard are considered for briquetting process by many studies but there is a need to study a possible environmental risk through the heavy metal emission, in the flue gas and ash, produced during the combustion of the briquettes. During the present work, a study of the energy and environmental performance of the combustion of briquettes was carried out. Four types of briquettes obtained in our previous study were used in this study [4]. The study consisted in analyzing the temperature fields, heavy metals in the flue gas and in the ash during the combustion of the four types of briquettes. The possibility of using ash as an amendment to soil was also studied.

\section{Materials and Methods}

\subsection{Characteristics of Briquettes}

The paper and cardboard were collected directly in the waste produced in the city of Ouagadougou. The briquettes were produced and characterized in the laboratory during our previous work [4]. The characteristics of the briquettes based on waste paper/cardboard used are summarized in the Table 1. The concerned characteristics are the density, the higher heating value (HHV) and the moisture content of the briquettes. 
Table 1. Characteristics of briquettes used in this study [4].

\begin{tabular}{cccc}
\hline Briquette & Density $\mathbf{( k g / \mathbf { m } ^ { 3 } )}$ & HHV (MJ/kg) & Moisture Content (\%) \\
\hline Type 1 (corrugated cardboard) & 486 & 15.83 & 7.5 \\
Type 2 (office paper) & 550 & 14.10 & 5.7 \\
Type 3 (mixture of paper waste) & 490 & 15.22 & 5.1 \\
Type 4 (mixture of paper and green waste) & 430 & 15.54 & 6.4 \\
\hline
\end{tabular}

\subsection{Study of Combustion}

The study of briquette combustion was conducted using two devices in order to analyze the temperature fields and the heavy metals content in the flues gas and ash.

\subsubsection{Analysis of Temperature Fields}

The device shown in Figure 1 was used for the study of the combustion of briquettes. The rotary kiln is a cylinder slightly inclined with a diameter of $88 \mathrm{~cm}$ and $108 \mathrm{~cm}$ of length. The refractory and insulation material of $4 \mathrm{~cm}$ and $5.6 \mathrm{~cm}$ of thickness respectively were placed in the rotary kiln. The flue gases were evacuated through a chimney of $8 \mathrm{~m}$ of length. The rotary kiln allowed the study of temperature fields during the combustion of briquettes. Two kilograms $(2 \mathrm{~kg})$ of briquettes were weighed and then arranged on a horizontal grid as shown in Figure 1. Five thermocouples were placed along a metal rod for temperature measurement. The thermocouples of type K were used for this purpose. The first thermocouple was placed close to the kiln gate and the four other thermocouples are regularly placed at $10 \mathrm{~cm}$ in order to cover the briquette bed formed on the grate. The measured temperatures were collected by a data logger connected to a computer. Inflammation of the fuel charge was done at the front of the oven (outward). Thus, the flame propagates from the front to the inside of the oven.

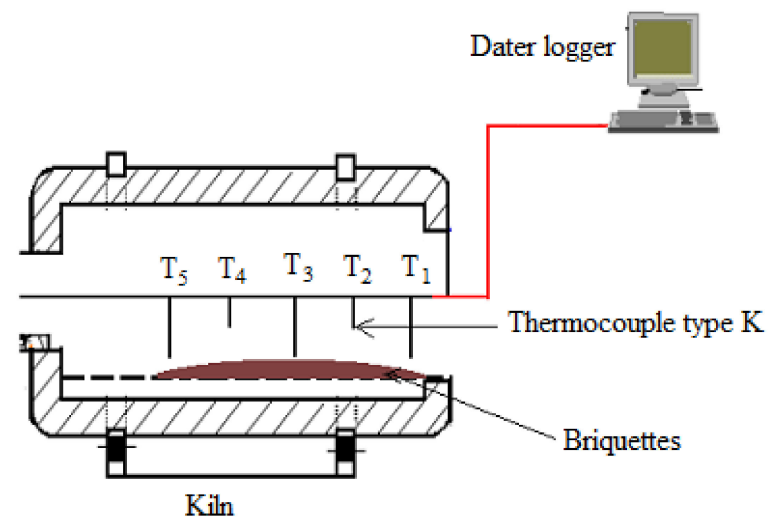

(A)

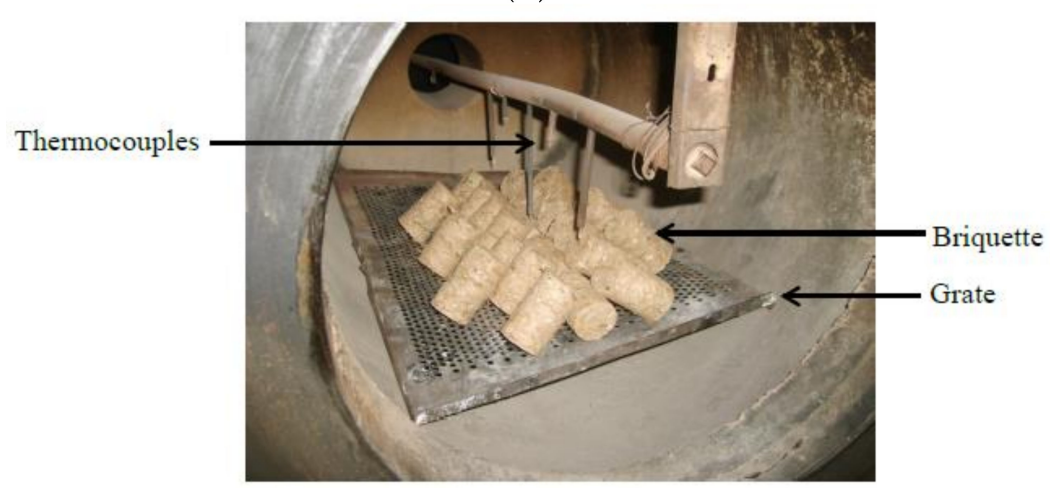

(B)

Figure 1. Experimental device of the briquettes combustion. (A) Schematic Diagram of the device; (B) Arrangement of briquettes in the rotary kiln. 
The established phase (or homogeneous) of the combustion is the main concern of the present study. The combustion is called in the established phase when all the reaction intermediates are released and are in the oxidation phase: this is the part of the combustion where we have the maximum of chemical reactions that occur. This step is characterized by the stabilization of the temperatures in the oven. The duration of the established phase of the combustion was estimated by considering the time spent between the beginning and the end of the combustion indicated by the rise of the temperature and the drop of the temperature respectively. In addition, the temperature of the established phase of the combustion was determined based on the temperature fields. Three tests were carried out for each type of briquette. The ash from each test was collected and weighed. The ash samples were digested according the method described by ISO 16968 [18] and the heavy metals content were determined by ICP-MS. The determination of nitrogen was done by mineralized the samples with $\mathrm{H}_{2} \mathrm{SO}_{4}$. The nitrogen content in the ash was determined by the Kjeldahl method. For the phosphorus content determination, $\mathrm{NaHCO}_{3}$ and the formed phosphate ions were treated with an ascorbic acid. The phosphorus $\left(\mathrm{P}_{2} \mathrm{O}_{5}\right)$ content was determined by dosing the emitted blue color with a spectrophotometer at $660 \mathrm{~nm}$ of wavelengths as described by Olsen et al. [19]. For the potassium $\left(\mathrm{K}_{2} \mathrm{O}\right)$ content determination, the ash sample was digested according to the method describe by the Part 2 of standard ISO 16967 [20]. Then the potassium content was determined by flame emission spectroscopy at a wavelength of $766.5 \mathrm{~nm}$. The heavy metal (i) content in the ash $\left(H M_{a s h}\right)_{i}$ is given by the Equation (1).

$$
\left(H M_{a s h}\right)_{i}=100 \frac{M_{a s h} C_{i, a s h}}{M_{\text {sample }}}
$$

$M_{a s h}, C_{i, a s h}$ and $M_{\text {sample }}$ are respectively the masse of collected ash in $\mathrm{kg}$, the concentration of the heavy metal determined in the ash sample in $\mathrm{mg}$ per $\mathrm{kg}$ and the masse of the briquette sample in $\mathrm{kg}$.

\subsubsection{Flue Gas Analysis}

The tubular kiln was used for the study of the fumes resulting from the combustion of the briquettes (Figure 2). A test bench has been created for this purpose. The tubular kiln of $88 \mathrm{~cm}$ represents the central part of the bench. A quart reactor of $120 \mathrm{~cm}$ long and $7 \mathrm{~cm}$ of internal diameter was placed inside the tubular kiln. The reactor temperature can be set up to a maximum of $1250{ }^{\circ} \mathrm{C}$. The air flow was fixed by a digital control box (Brooks Microprocessor Control \& Read Out Unit Models 0154) connected to a Brooks flow meter of type 5850E. Mass samples of $500 \mathrm{mg}$ are weighed and placed inside the preheated oven at the set temperature. The air flow was set at $1.07 \mathrm{liter} / \mathrm{min}$. The combustion takes place in a few minutes. The flue gases were bubbled to a bottle containing $250 \mathrm{~mL}$ of solution of $5 \%$ of $\mathrm{HNO}_{3}$. The resulted ash from the combustion was weighed after each trial.

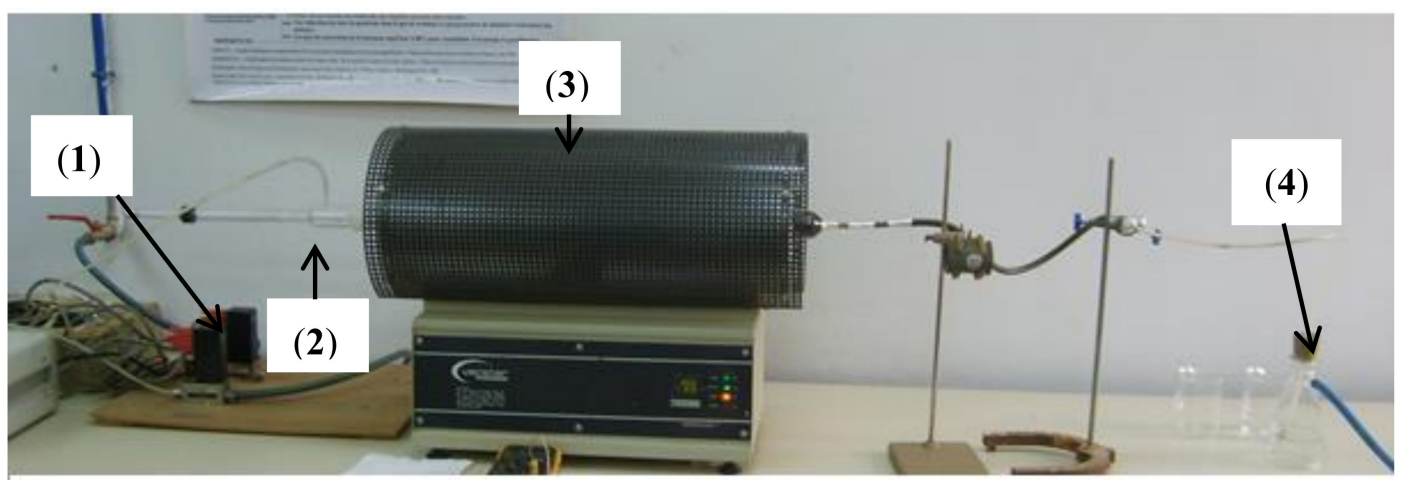

Figure 2. Experimental device for the briquettes combustion in a tubular furnace: (1) Flowmeter; (2) Quart reactor; (3) Tubular kiln; (4) Solution of 5\% $\mathrm{HNO}_{3}$. 
For each type of briquette three combustion tests were performed to ensure better reliability of the results. The ash fractions $(A s h)$ obtained in the tubular and rotary kiln devices were calculated on wet basis by the Equation (2).

$$
\text { Ash }=100 \frac{M_{\text {ash }}}{M_{\text {sample }}}
$$

The bubbling in the acid solution of the flue gas at the outlet of the reactor was carried out in order to trap the heavy metals. The analysis of the contents of these metals was carried out by ICP-MS. The following heavy metals were analyzed: Arsenic (As), Cadmium (Cd), Mercury (Hg), Lead $(\mathrm{Pb})$ and Manganese $(\mathrm{Mn})$. This study was conducted to simulate the combustion under the temperature obtained during the combustion in the rotary kiln. The heavy metal (i) content in the flue gas $\left(H M_{\text {flue gas }}\right)_{i}$ is given by the Equation (3).

$$
\left(\mathrm{HM}_{\text {flue gas }}\right)_{i}=100 \frac{V_{\text {solution }} C_{i, \text { solution }}}{M_{\text {sample }}}
$$

$V_{\text {solution }}$ and $C_{i, \text { solution }}$ are respectively the volume of the acid solution in liters and the concentration of the heavy metal determined in the solution in mg per liter.

\section{Results and Discussion}

\subsection{Temperature Fields and Ash Fractions}

The temperature fields during the combustion of the four types of briquettes were shown in the Figure 3.

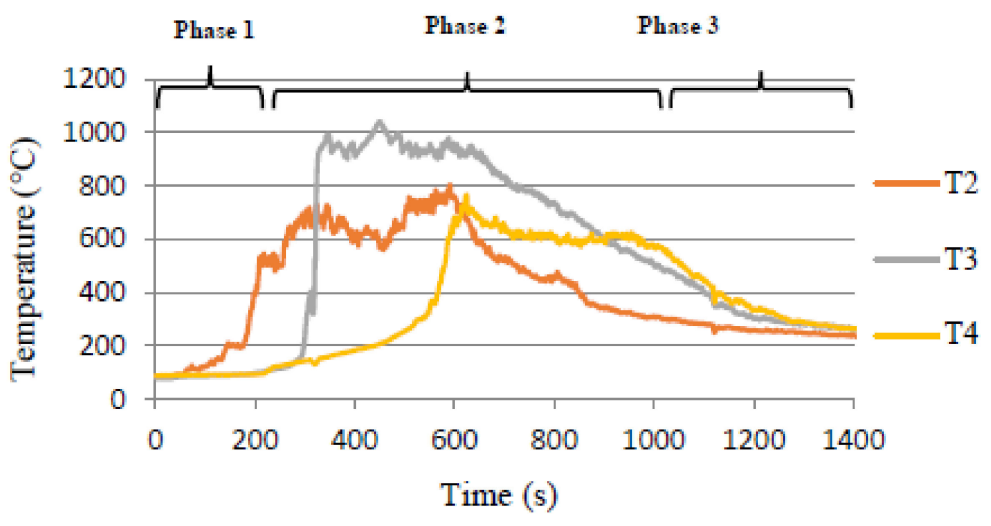

(A)

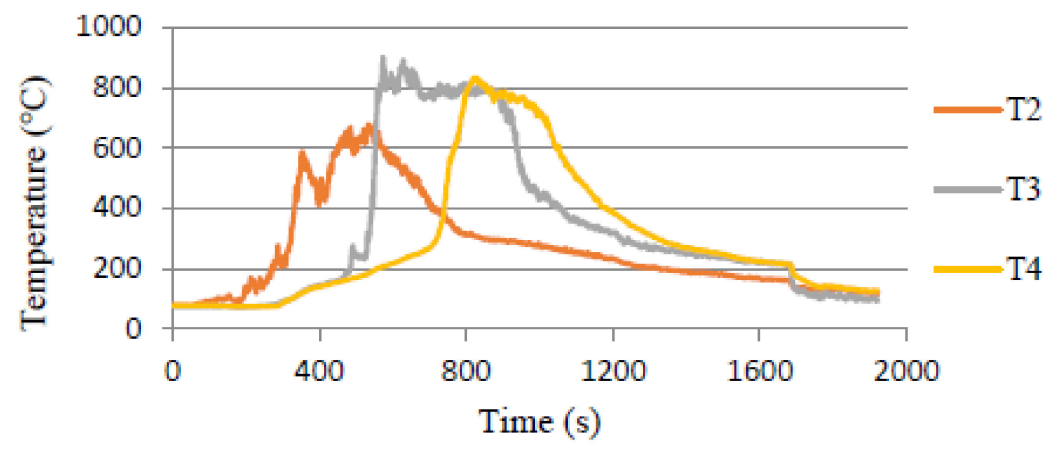

(B)

Figure 3. Cont. 


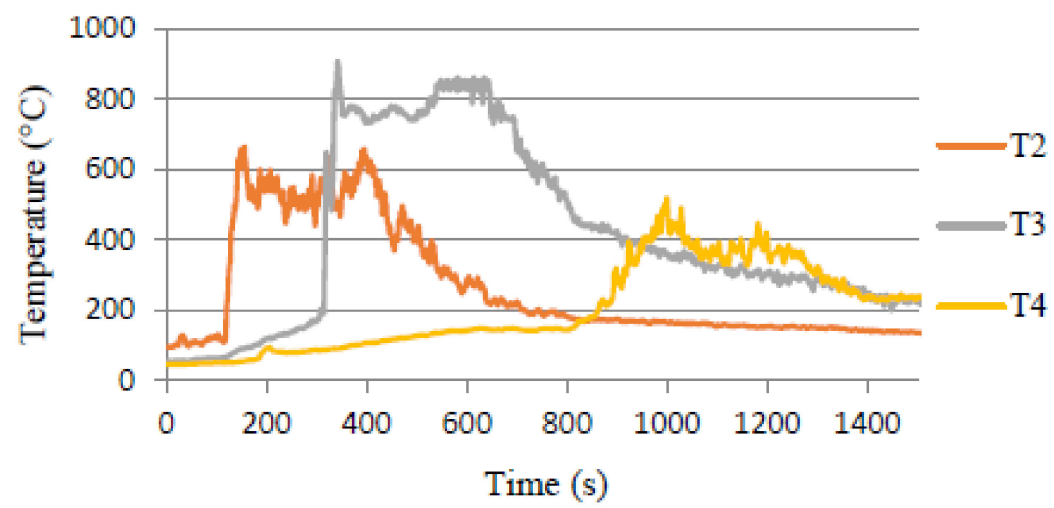

(C)

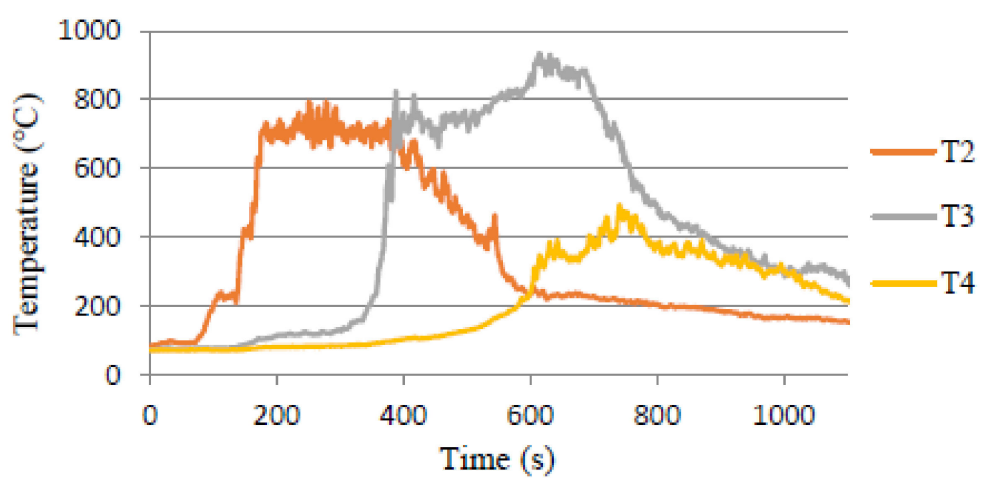

(D)

Figure 3. Temperature variation versus time for: (A) Type 1 briquettes (corrugated cardboard); (B) Type 2 briquettes (office paper); (C) Type 3 briquettes (mixture of paper waste); (D) Type 4 briquettes (mixture of paper and green waste).

Only the thermocouple temperatures $\mathrm{T}_{2}, \mathrm{~T}_{3}$ and $\mathrm{T}_{4}$ were represented. Indeed, these thermocouples were placed above the solid bed. This was not the case of $\mathrm{T}_{1}$ which was placed in combustion initiation zone and $\mathrm{T}_{5}$ which was placed at the combustion end zone. The temperature rises were shifted chronologically from $\mathrm{T}_{2}$ to $\mathrm{T}_{4}$ (Figure 3); this is explained by the fact that the propagation of the flame was done along the solid bed from outside to inside the furnace. The rise of temperatures characterized the phase 1 of the combustion which represents the phase of the initiation (Figure 3A). The established phase of the combustion is also observed on the temperature fields during the combustion of each type of briquette (Phase 2). The temperature drop characterizes the end of combustion (Phase 3). The average temperature of the established phase of the combustion and the duration of the combustion obtained during the combustion are given by the Table 2 . The results showed a better combustion for the briquette of Type 1 made of corrugated cardboard for which the highest mean temperature was recorded. This result is predictable because briquettes made of corrugated cardboard have the highest calorific value, $15.83 \mathrm{MJ} / \mathrm{kg}$. After briquettes made of corrugated cardboard, come the briquettes of Type 3 (mixture of papers) and Type 4 (mixture with green waste) which had the same mean temperature since their $\mathrm{HHV}$ are similar $(15.22 \mathrm{MJ} / \mathrm{kg}$ and $15.54 \mathrm{MJ} / \mathrm{kg}$ respectively). 
Table 2. Summary of combustion times and average temperatures of the established phase of combustion.

\begin{tabular}{ccccc}
\hline Briquette Type & Type 1 & Type 2 & Type 3 & Type 4 \\
\hline Combustion time $(\mathrm{min})$ & 10.5 & 11.0 & 18.5 & 12.5 \\
Temperature $\left({ }^{\circ} \mathrm{C}\right)$ & 950 & 750 & 800 & 800 \\
\hline
\end{tabular}

The briquettes which produced the lowest mean temperature are the briquettes made from office paper. This fact is also predictable because office papers have the lowest HHV $(14.10 \mathrm{MJ} / \mathrm{kg})$. Furthermore, the briquettes made of corrugated cardboard burned quickly than the other briquettes. The high cellulose content of cardboard is the base of the rapid degradation since cellulose degrades rapidly and at low temperature according to Sorum et al. [5]. The duration of the combustion was quite the same for briquettes of Types 1,2 and 4. The duration of the combustion was higher for briquettes of Type 3 (18 $\mathrm{min}$ ) comparatively to other briquettes. This can be explained by the fact that the papers in the category "commercial printing paper" were composed of additives giving them a more flame retardant character than the others.

The ash fractions produced by the combustion in the rotary and tubular furnace were analyzed in the present work (Figure 4). In general, the ash proportions were almost the same regardless of the device used (rotary kiln for large-scale tests and tubular kiln for small-scale tests). The ash content varied from $10 \%$ to $16 \%$, which will lead to a large production of ash during the combustion of briquettes in industrial plants. The ash content obtained for the paper/cardboard are higher than those obtained for the raw wood.

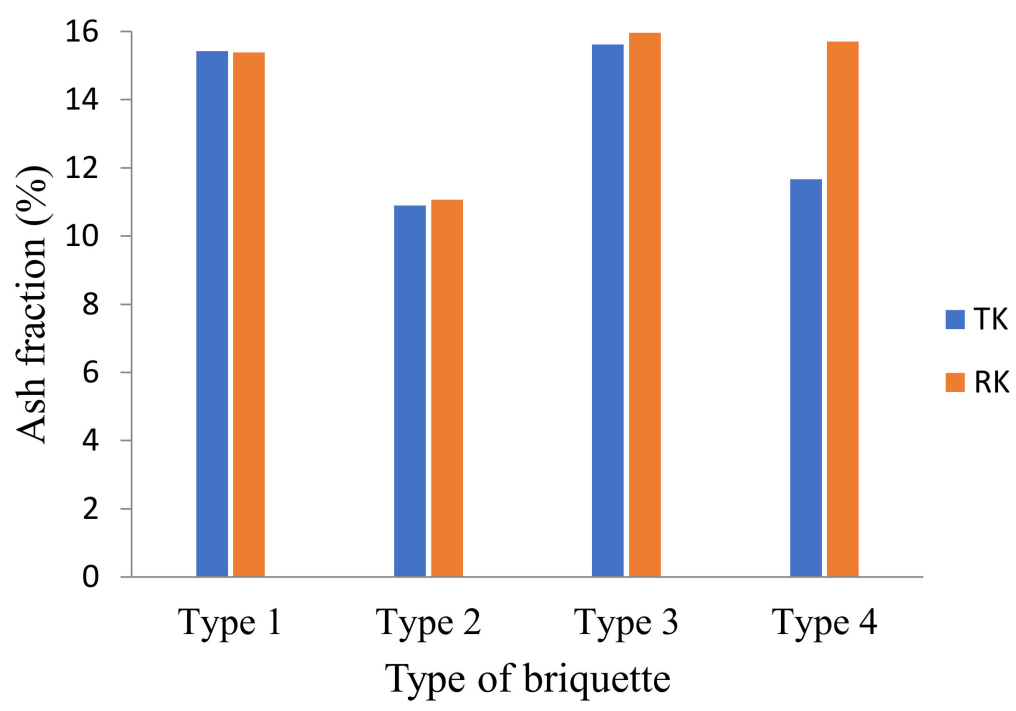

Figure 4. Ash fraction in the rotary kiln (RK) and the tubular kiln (TK).

This fact can be explained by paper manufacturing process which reduces considerably the lignin and hemicellulose content of the biomass and added the mineral matters to enhance the paper properties. However, the ashes content are lower than those obtained by Sorum et al. [5] since a part of the ashes may be evaporated or entrained by the flowing flue gas during the combustion as mentioned by Jenkins et al. [8]. The fly ash was not accounted in the present study contrary to the protocol followed for the ash content determination. In addition, the differences in the ash content are also due to the heterogeneities of the waste paper/cardboard. 


\subsection{Heavy Metals in the Flue Gas and Ash}

The heavy metals content (reported to a kg of fuel) in the flue gas emitted in the tubular furnace and in the collected ash in the rotary kiln were presented in the Table 3. The heavy metals content in the ash (reported to a $\mathrm{kg}$ of ash) were presented in Table 4 . The tests in the tubular furnace were carried out at the average temperatures obtained in the rotary kiln, thus the obtained results were compared. Indeed, the combustion temperature and the fuel moister content are the most influencing factors of the heavy metal emission during the biomass combustion [21,22]. According to Wei et al. [22] the importance of the moisture content is due to its impact on combustion temperature.

Due to the high temperature of the combustion $\left(750^{\circ} \mathrm{C}\right.$ to $\left.950{ }^{\circ} \mathrm{C}\right)$, the heavy metal contained in the raw paper waste were predominantly transferred into the flue gas than into the ash as shown in the Table 3. According to Kovacs et al. [15], high percent of the heavy metals may be content in the flue gas even at relatively low temperature of $250{ }^{\circ} \mathrm{C}$. Indeed, the temperature increases the heavy metal content in flue gas at the expense of ash [21]. The low volatilization temperature of heavy metal, particularly $\mathrm{Hg}$, $\mathrm{Cd}$ and $\mathrm{Pb}$, explained their large content in the flue gas comparatively to the bottom ash as shown in the literature [21,23]. However, the Mn was more present in the ash than in the flue gas. The low volatility of Mn explained this fact as it was confirmed by Yanjun et al. [21].

Table 3. Heavy metals contained in the flue gas and in the bottom ashes in $\mathrm{mg}$ metal $/ \mathrm{kg}_{\text {fuel }}$.

\begin{tabular}{cccccc}
\hline Briquettes & As & $\mathbf{C d}$ & $\mathbf{H g}$ & $\mathbf{M n}$ & $\mathbf{P b}$ \\
\hline \multicolumn{7}{c}{ In the flue gas } \\
Type 1 & 2.58 & 0.82 & 7.07 & 68.32 & 42.78 \\
Type 2 & 7.83 & 1.32 & 6.01 & 205.01 & 53.58 \\
Type 3 & 2.09 & 0.97 & 6.16 & 74.96 & 38.93 \\
Type 4 & 2.92 & 0.84 & 5.31 & 87.62 & 37.97 \\
Type 1 & 1.78 & 0.22 & 0.20 & 91.32 & 15.24 \\
Type 2 & 1.73 & 0.14 & 0.36 & 77.85 & 5.25 \\
Type 3 & 1.06 & 0.14 & 0.26 & 76.44 & 12.60 \\
Type 4 & 0.92 & 0.25 & 0.75 & 90.96 & 10.73 \\
\hline
\end{tabular}

The briquette of type 2, made of office paper, had the higher emission of heavy metal comparatively to the others type of briquettes since its combustion produced a highest mass of heavy metal which were concentrated in the flue gas. This fact may be explained by the presence of considerable heavy metals in the office paper due to the use of this type of paper for printing and writing. However, the mercury and cadmium emission were similar for all type of briquettes. Otherwise, the differences between the emissions of heavy metal in the flue gas were low for the other types of briquettes. For the ash, the heavy metal content was higher for the briquette of type 1, made of corrugated cardboard, comparatively to the other type of briquettes (Tables 3 and 4). Even though the highest temperature was achieved during the combustion of briquette of type 1, their high moisture content may favor the concentration of heavy metal in the collected ash. According to Yanjun et al. [21], the moisture content reduces the transfer of heavy metal in the flue gas. In addition, the low ash content of the briquette of Type 1 (Figure 3) increased the concentration of heavy metal in the ash (Table 4).

Note that the $\mathrm{Pb}, \mathrm{Hg}$ and $\mathrm{Mn}$ contents in the flue gas and collected ash were higher than that reported in the raw biomass by the literature $[15,24]$. In contrast, the $\mathrm{Cd}$ and As content were similar to those reported in the raw biomass by Kovacs et al. [15]. Thus, the excess of $\mathrm{Pb}, \mathrm{Hg}$ and $\mathrm{Mn}$ may be resulted to the impurity of waste paper mainly the ink and the additives of the paper manufacturing process. The heavy metal content in the ash is also important for analyzing their impact on soil quality since ash could be used to amend the soil. In this purpose, the toxicity of heavy metals in the ashes should be evaluated before considering any use as fertilizer. These heavy metals are indeed taken into account in the definition of standards for the spreading of mineral fertilizer on agricultural land. Note that, the heavy metals content obtained in the present study are largely lower than those found 
in the municipal waste by Xiao et al. [25]. In addition, the contents of heavy metals were compared to the limit values reported in the law of Burkina Faso [26] and in the Australian standard [27] as shown by Table 4 .

Table 4. The heavy metals content in the ash and the limit value in heavy metals for application of ash in soil $\left(\mathrm{mg}_{\text {metal }} / \mathrm{kg}_{\text {ash }}\right)$.

\begin{tabular}{ccccccc}
\hline Heavy Metals & As & Cd & Hg & Mn & Pb \\
\hline Heavy metals content in ash & & & \\
Type 1 (corrugated cardboard) & 16.08 & 2.02 & 1.80 & 825.28 & 137.69 \\
\hline Type 2 (office paper) & 11.21 & 0.93 & 2.35 & 505.80 & 34.13 \\
Type 3 (mixture of paper waste) & 6.65 & 0.89 & 1.61 & 478.80 & 78.96 \\
Type 4 (mixture of paper and green waste) & 5.86 & 1.56 & 4.80 & 579.45 & 68.37 \\
Limit value of heavy metals & & & \\
Law of Burkina Faso [26] & - & 40 & 25 & - & 1200 \\
Narodoslawsky and Obernberger, [27] & 20 & 10 & - & - & 500 \\
\hline
\end{tabular}

For all the heavy metals analyzed, the ash obtained for all briquettes types can be used for soil amendment since the heavy metal content were under the limits values given by Table 4 . However, the agronomic value must be determined by considering the fertilizing substances (NPK) content in the ash. This issue was addressed in the next section.

\subsection{Ash Proportion and NPK Content}

The ash could be valorized in the fields to amend soils, as said previously. The value of ash as fertilizer is mainly evaluated through it content of NPK. Thus, the contents of NPK have been determined and given in Table 5. The obtained fractions of NPK are comparable to those obtained for waste paper by other authors [8]. However, the obtained fractions of NPK are considerably lower than those obtained for the ash coming from the most biomass species as shown in the literature [8]. The manufacturing process of the paper may reduce the NPK fractions since these fractions are lower than those obtained for the parent wood used for paper production.

Table 5. NPK contents in the ash and minimum content of NPK for the ash qualification to fertilizers.

\begin{tabular}{cccccc}
\hline NPK & Type 1 & Type 2 & Type 3 & Type 4 & Minimum Content [28] \\
\hline $\mathrm{N}(\%)$ & 0.003 & 0.010 & 0.003 & 0.011 & 1 \\
$\mathrm{P}_{2} \mathrm{O}_{5}(\%)$ & 0.136 & 0.179 & 0.090 & 0.224 & 2 \\
$\mathrm{~K}_{2} \mathrm{O}(\%)$ & 0.494 & 1.198 & 0.353 & 1.408 & 5 \\
$\mathrm{~N}+\mathrm{P}_{2} \mathrm{O}_{5}+\mathrm{K}_{2} \mathrm{O}$ & 0.633 & 1.387 & 0.446 & 1.644 & 7 \\
\hline
\end{tabular}

The standard NF U 42001 [28] gave the minimum levels of nitrogen, phosphorus and potassium (NPK) to qualify ash as fertilizer. The NPK contents obtained for the four types of briquettes were below the minimum value required by the standard NF U 42001, [28]. Thus, ash collected cannot be standardized as fertilizer according to the standard. However, in the context of a use in co-composting, the mixture of ash with other elements, may allow to obtain a product whose fertilizer standardization is possible.

\section{Conclusions}

Briquettes made of waste paper produced in Ouagadougou were combusted in the present work. The temperature variation, the heavy metal in the flue gas and the produced ash and NPK content in the produced ash were studied in the present work. The combustion of the briquette made of corrugated cardboard achieved the highest mean temperature of $950^{\circ} \mathrm{C}$ and lowest duration of 10.5 min during 
the established phase of the combustion. The lowest mean temperature of the established phase was achieved for the combustion of briquettes of type 2 due to their low HHV. The highest combustion time was obtained for the combustion of briquettes made of the mixture of all paper waste due to flame retardant which may be present in the mixture of waste paper and cardboard. The combustion produced considerable residual ash which proportion varied from $11 \%$ to $16 \%$ of the raw briquettes mass. The analysis of the ash and the flue gas shown that large proportions of the heavy metal were transferred predominantly in the flue gas than in the ash. In addition, the manufacturing process and the usage of paper had increased some heavy metal content $(\mathrm{Pb}, \mathrm{Hg}$ and $\mathrm{Mn}$ ) comparatively to the parent wood. The heavy metal contents in the ash were under the limit content fixed by the standard in the context of soils amendment. Thus, the ash obtained after the briquettes combustion can be used to amend soils. For this purpose, the ash may be mixed with other element in order to improve fertilizer content since the ash fraction of NPK are lower than the minimum required by the standard.

Author Contributions: H.G.I. realized the experiments and wrote the paper. S.K.O. and A.Y. conceived and supervised the study. O.S. contributed in the data analysis. The paper presentation and formulation was improved by T.D., J.K. had made a critical review which improved the scientific quality of the paper.

Funding: This research received no external funding.

Acknowledgments: The authors want to acknowledge Dissa Alfa Omar and Sanon Pierre for their assistance with the present work.

Conflicts of Interest: The authors declare no conflict of interest.

\section{References}

1. Tezanou, J. Evaluation Environnementale et Technique de la Gestion des Déchets Ménagers de Ouagadougou: Schémas de Gestion et Expérimentation de Traitement Thermique. Ph.D. Thesis, Université de Poitiers, Poitiers, France, 2003; p. 27.

2. Karna, A.; Engstrom, J.; Kutnlahtim, T. Life cycle analysis of newsprint. In Proceedings of the 2nd Research Forum on Recycling, Canadian Pulp and Paper Association, Montreal, QC, Canada, 5-7 October 1993; pp. 171-178.

3. Merrild, H.; Anders, D.; Christensen, T.H. Life cycle assessment of waste paper management: The importance of technology data and system boundaries in assessing recycling and incineration. Resour. Conserv. Recycl. 2008, 52, 1391-1398. [CrossRef]

4. Harouna, I.G.; Ouiminga, S.K.; Daho, T.; Arsène, H.Y.; Sougoti, M.; Koulidiati, J. Characterization of Briquettes Coming From Compaction of Paper and Cardboard Waste at Low and Medium Pressures. Waste Biomass Valoriz. 2014, 5, 725-731.

5. Sorum, L.; Gronli, M.G.; Hustad, J.E. Pyrolysis characteristics and kinetics of municipal solid waste. Fuel 2001, 80, 1217-1227. [CrossRef]

6. Von Wilpert, K.; Bosch, B.; Puhlmann, H.; Zirlewagen, D. Wood ash recycling-An appropriate measure to close nutrient cycles in forests. In Proceedings of the 4th Central European Biomass Conference, Graz, Austria, 15-18 January 2014.

7. Hallenbarter, D.; Landolt, W.; Bucher, J.B.; Schutz, J.P. Effects of wood ash and liquid fertilization on the nutritional status and growth of Norway spruce (Picea abies (L.) Karst). Forstwiss. Centralbl. 2002, 121, 240-249. [CrossRef]

8. Jenkins, B.M.; Baxter, L.L.; Miles, T.R., Jr.; Miles, T.R. Combustion properties of biomass. Fuel Process. Technol. 1998, 54, 17-46. [CrossRef]

9. Jokinen, K.; Siren, K.; Osmonen, R.M. Quality aspects of recycled fibre. World Pap. 1995, 220, 31-33.

10. Vassilev, S.V.; Baxter, D.; Andersen, L.K.; Vassileva, C.G.; Morgan, T.J. An overview of the organic and inorganic phase composition of biomass. Fuel 2012, 94, 1-33. [CrossRef]

11. Ginebreda, A.; Guillen, D.; Barcelo, D.; Darbra, R.M. Additives in the paper industry. In Global risk-based management of chemical additives I: Production, Usage and Environmental Occurrence, 1st ed.; Bilitewski, B., Darbra, R.M., Barcelo, Eds.; Springer-Verlag: Heildenberg, Germany, 2012; Volume 18, pp. 11-34. ISBN 978-3-642-24876-4. 
12. Pekarovicova, A.; Wu, Y.J.; Fleming, P. Quality analysis of gravure spot color reproduction with an ink jet printer. J. Imaging Sci. Technol. 2008, 52, 60501-60509.

13. Conti, M.E. Heavy metals in food packagings. In Mineral Components in Food, 1st ed.; Nriagu, J., Szefer, P., Eds.; CRC Press: Boca Raton, FL, USA, 2006; pp. 339-362. ISBN 978-1-420-00398-7.

14. Zalewski, S. Design, graphics arts, and environment. Thesis, RIT Roschester Institute of Technology, Rochester, NY, USA, 1994.

15. Kovacs, H.; Katalin, S.; Tamás, K. Theoretical and experimental metals flow calculations during biomass combustion. Fuel 2016, 185, 524-531. [CrossRef]

16. Lanzerstorfer, C. Chemical composition and physical properties of filter fly ashes from eight grate-fired biomass combustion plants. J. Environ. Sci. 2015, 30, 191-197. [CrossRef] [PubMed]

17. Nurmesniemi, H.; Makela, M.; Poykio, R.; Manskinen, K.; Dahl, O. Comparison of the forest fertilizer properties of ash fractions from two power plants of pulp and paper mills incinerating biomass-based fuels. Fuel Process. Technol. 2012, 104, 1-6. [CrossRef]

18. ISO 16968. Solid Biofuels—Determination of Minor Elements; ISO: Geneva, Switzerland, 2015.

19. Olsen, S.R.; Cole, C.V.; Watanabe, F.S.; Dean, L.A. Estimation of Available Phosphorus in Soils by Extraction with Sodium Bicarbonate; Circular 939; United States Department Of Agriculture: Washington, DC, USA, 1954; Volume 939, pp. 1-19.

20. ISO 16967. Solid Biofuels-Determination of Major Elements-Al, Ca, Fe, Mg, P, K, Si, Na and Ti; ISO: Geneva, Switzerland, 2015.

21. Yanjun, H.; Jiubing, W.; Kai, D.; Jianli, R. Characterization on Heavy Metals Transferring into flue gas during Sewage Sludge Combustion. Energy Procedia 2014, 61, 2867-2870.

22. Wei, Z.; Yindong, T.; Huanhuan, W.; Long, C.; Langbo, O.; Xuejun, W.; Guohua, L.; Yan, Z. Emission of Metals from Pelletized and Uncompressed Biomass Fuels Combustion in Rural Household Stoves in China. Sci. Rep. 2014, 4, 5611.

23. Van de Velden, M.; Dewil, R.; Baeyens, J.; Josson, L.; Lanssens, P. The distribution of heavy metals during fluidized bed combustion of sludge (FBSC). J. Hazard. Mater. 2008, 151, 96-102. [CrossRef] [PubMed]

24. Demirbas, A. Influence of Gas and Detrimental Metal Emissions from Biomass Firing and Co-Firing on Environmental Impact. Energy Sources 2005, 27, 1419-1428. [CrossRef]

25. Xiao, Z.; Xingzhong, Y.; Hui, L.; Longbo, J.; Lijian, L.; Xiaohong, C.; Guangming, Z.; Fei, L.; Liang, C. Chemical speciation, mobility and phyto-accessibility of heavy metals in fly ash and slag from combustion of pelletized municipal sewage sludge. Sci. Total Environ. 2015, 536, 774-783. [CrossRef] [PubMed]

26. Décret. Le Décret N 2001-185/PRES/PM/MEE du 07 mai 2001; Portant Fixation des Normes de Rejets de Polluants Dans L'air, L'eau et le sol; Journal officiel: Ouagadougou, Burkina Faso, 2001.

27. Narodoslawsky, M.; Obernberger, I. From waste to raw material-the route from biomass to wood ash for cadmium and other heavy metals. J. Hazard. Mater. 1996, 50, 157-168. [CrossRef]

28. NF U42-001. Engrais-Dénominations et Spécifications; 1981. Available online: https:/ /www.boutique.afnor.org/ norme/nf-u42-001/fertilizers-types-and-specifications/article/743864/fa032284 (accessed on 8 July 2018).

(C) 2018 by the authors. Licensee MDPI, Basel, Switzerland. This article is an open access article distributed under the terms and conditions of the Creative Commons Attribution (CC BY) license (http:// creativecommons.org/licenses/by/4.0/). 